\title{
Dissolution of wollastonite during the experimental manipulation of Hubbard Brook Watershed 1
}

\author{
STEPHEN C. PETERS ${ }^{1, *}$, JOEL D. BLUM ${ }^{1}$, CHARLES T. DRISCOLL ${ }^{2}$ and \\ GENE E. LIKENS ${ }^{3}$ \\ ${ }^{I}$ Department of Geological Sciences, University of Michigan, Ann Arbor, MI 48109, USA; ${ }^{2}$ Department \\ of Civil and Environmental Engineering, Syracuse University, Syracuse, NY 13244, USA; ${ }^{3}$ Institute of \\ Ecosystem Studies, Millbrook, NY 12545, USA; *Author for correspondence (e-mail: scp2@lehigh.edu; \\ phone: (610) 758-3660; fax: (610) 758-3677. Address as of September, 2003: Department of Earth and \\ Environmental Sciences, LeHigh University, Bethlehem, PA 18015)
}

Received 24 June 2002; accepted in revised form 20 December 2002

\begin{abstract}
Powdered and pelletized wollastonite $\left(\mathrm{CaSiO}_{3}\right)$ was applied to an 11.8 ha forested watershed at the Hubbard Brook Experimental Forest (HBEF) in northern New Hampshire, U.S.A. during October of 1999. The dissolution of wollastonite was studied using watershed solute mass balances, and a ${ }^{87} \mathrm{Sr} /$ ${ }^{86} \mathrm{Sr}$ isotopic tracer. The wollastonite $\left({ }^{87} \mathrm{Sr} /{ }^{86} \mathrm{Sr}=0.70554\right)$ that was deposited directly into the stream channel began to dissolve immediately, resulting in marked increases in stream water Ca concentrations and decreases in the ${ }^{87} \mathrm{Sr} /{ }^{86} \mathrm{Sr}$ ratios from pre-application values of $0.872 \mathrm{mg} / \mathrm{L}$ and 0.72032 to values of $\sim 2.6 \mathrm{mg} / \mathrm{L}$ and 0.71818 respectively. After one calendar year, $401 \mathrm{~kg}$ of the initial $631 \mathrm{~kg}$ of wollastonite applied to the stream channel was exported as stream dissolved load, and $230 \mathrm{~kg}$ remained within the stream channel as residual $\mathrm{CaSiO}_{3}$ and/or adsorbed on streambed exchange sites. Using previously established values for streambed Ca exchange capacity at the HBEF, the dissolution rate for wollastonite was found to be consistent with dissolution rates measured in laboratory experiments. Initially, $\mathrm{Ca}$ was released from the mineral lattice faster than $\mathrm{Si}$, resulting in the development of a Cadepleted leached layer on mineral grains. The degree of preferential Ca release decreased with time and reached stoichiometric proportions after $\sim 6$ months. Using $\mathrm{Sr}$ as a proxy for $\mathrm{Ca}$, the $\mathrm{Ca}$ from wollastonite dissolution can be accurately tracked as it is transported through the aquatic and terrestrial ecosystems of this watershed.
\end{abstract}

\section{Introduction}

Chemical weathering of silicate minerals is of central importance to understanding global biogeochemical cycles and long-term trends in the climate of the Earth (Berner et al. 1983; Kump et al. 2000). Chemical mass balance techniques in small watersheds have frequently been used to estimate mineral weathering rates (e.g., Casey et al. (1993); Drever and Zobrist (1992); Likens and Bormann (1995); Mast et al. (1990); Paces (1983) and Velbel (1985)). In this paper, we present two years of geochemical data from a watershed scale experiment where wollastonite $\left(\mathrm{CaSiO}_{3}\right)$ was applied to a forested catchment, with the goal of characterizing the fate of material applied directly to the stream channel. The experimental design allowed us to compare laboratory studies of the rate and mechanism of wollastonite dissolution with a large-scale experiment in a natural stream channel. 


\section{Field location \& description}

The Hubbard Brook Experimental Forest (HBEF) is located within the White Mountain National Forest of northern New Hampshire ( $\left.43^{\circ} 56^{\prime} \mathrm{N}, 71^{\circ} 45^{\prime} \mathrm{W}\right)$. This study was conducted within the 11.8 ha south-facing watershed 1 (W-1, Figure 1). Watershed 1 is a third order perennial catchment with a northern hardwood forest of primarily sugar maple, (Acer saccharum), American beech (Fagus grandifolia), and yellow birch (Betula alleghaniensis), with red spruce (Picea rubens), balsam fir (Abies balsamea), and white birch (Betula papyrifera) at the highest elevations within the watershed. The ridgeline at $747 \mathrm{~m}$ forms the upper boundary of the watershed, with the east and west boundaries delineated by local topographic highs. The bottom of the watershed is delineated by the stream-gauging weir at $488 \mathrm{~m}$ elevation. The watershed is underlain by the Silurian age upper Rangeley formation, a rusty weathering pelitic schist of sillimanite metamorphic grade. The bedrock is covered with a variably thin $(0-3 \mathrm{~m})$ layer of Pleistocene ice-contact deposits with Spodosols (Haplorthods) developed to an average depth of $60 \mathrm{~cm}$ (Johnson et al. 2000, 1991).

Studies of the interactions between chemical weathering and solute fluxes have been investigated at the HBEF for over 30 years (Johnson et al. 1981, 1968; Likens and Bormann 1995). Precipitation input to $\mathrm{W}-1$ averages $130 \mathrm{~cm} / \mathrm{yr}$, with stream output accounting for $80 \mathrm{~cm}$; and evapotranspiration the remaining $50 \mathrm{~cm}$ (Federer et al. 1990; Likens and Bormann 1995). In 1999-2000, stream discharge ranged from 0 to $300 \mathrm{~L} / \mathrm{s}$, with a median value of $1.4 \mathrm{~L} / \mathrm{s}$. The stream flowed nearly continuously throughout this study, with undetectable discharge occurring for only two days during the two-year period. High flow events have been used to characterize the hydrologic flowpaths that influence the concentration of elements during stormflow generation (Hogan et al. 2000). Both $\mathrm{Ca}$ and $\mathrm{Sr}$ concentrations were found to be nearly independent of discharge, while $\mathrm{Si}$ and $\mathrm{Na}$ exhibited slight dilution during periods of increased flow.

The long-term depletion of $\mathrm{Ca}$ from the soil exchange complex has been observed in this (Likens et al. 1996, 1998) and other nearby watersheds (e.g., Bailey et al. (1996) and Hyman et al. (1998)), and provided the impetus to investigate the watershed response to the experimental addition of $\mathrm{Ca}$. As part of a larger project designed to study the effects of Ca supply on the structure and function of a basepoor forested ecosystem, Ca was applied by helicopter to the watershed forest floor in the form of the mineral wollastonite. The extensive monitoring of the watershed and the accurate chemical and isotopic characterization of the wollastonite allows the dissolved material to be traced with a high degree of sensitivity during transport through the ecosystem, providing an ideal opportunity for the study of silicate weathering rates. The use of $\mathrm{Ca} / \mathrm{Sr}$ and ${ }^{87} \mathrm{Sr} /{ }^{86} \mathrm{Sr}$ ratios to study Ca biogeochemistry has been discussed previously (e.g., Capo et al. (1998)) and has been applied successfully to studies of the Hubbard Brook Experimental Forest and other New England watersheds (e.g., Blum et al. (2000, 2002) and Bailey et al. (1996)). In this study, ${ }^{87} \mathrm{Sr} /{ }^{86} \mathrm{Sr}$ and $\mathrm{Ca} / \mathrm{Sr}$ ratios are used to apportion stream water solutes to either wollastonite dissolution or stream background. These solute fluxes can then 


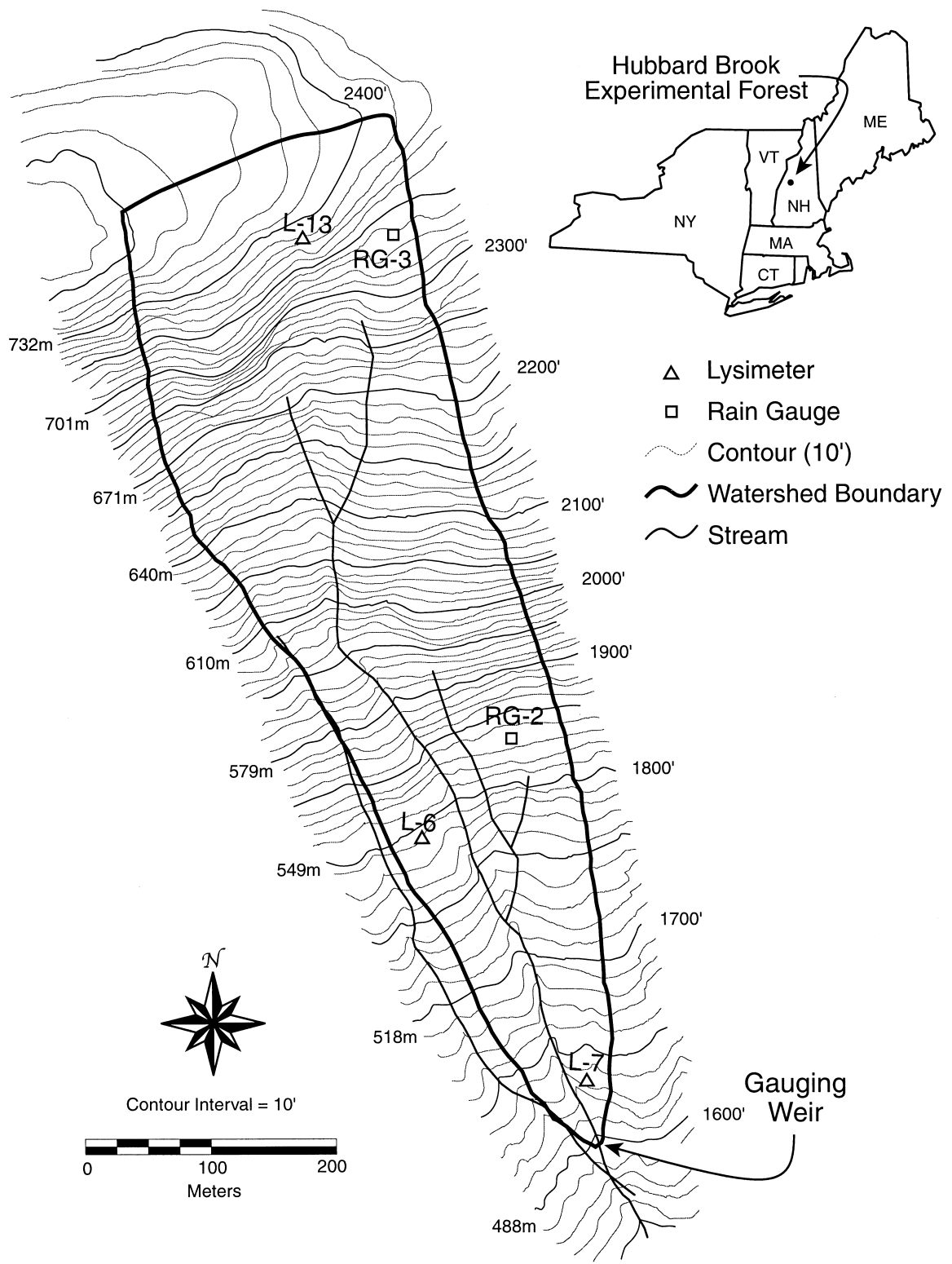

Figure 1. Location map of Hubbard Brook Experimental Forest and Watershed-1.

be utilized to calculate export rates for the dissolving wollastonite, resulting in a measurement of the dissolution rate. Before presenting the results of the field application, we review a few previous field-based $\mathrm{Ca}$ manipulation experiments, and the most relevant laboratory wollastonite dissolution experiments. 


\section{Previous Ca manipulation experiments}

In an experiment designed to examine the stream response to the addition of base cations, solutions of $\mathrm{CaCl}_{2}$ and $\mathrm{NaHCO}_{3}$ were added to two parallel streams at the HBEF (Hall et al. 2001). The manipulated stream reaches were located approximately $250 \mathrm{~m}$ downstream of the watershed-scale experiment described in this study, and have comparable $\mathrm{pH}$ values to $\mathrm{W}-1$ ( $\mathrm{pH}$ 5.6-7). $\mathrm{Both}_{\mathrm{CaCl}_{2}}$ and $\mathrm{NaHCO}_{3}$ were added to one stream, while only $\mathrm{CaCl}_{2}$ was added to the other stream, at variable rates in order to maintain a stream Ca concentration of $\sim 120 \mu \mathrm{eq} / \mathrm{L}$. Solution chemistry was measured above and $50-80 \mathrm{~m}$ below the addition site. Calcium was preferentially retained relative to $\mathrm{Cl}$ in both stream reaches, with more adsorption observed in the stream that received both $\mathrm{CaCl}_{2}$ and $\mathrm{NaHCO}_{3}$, resulting in a positive relationship between $\mathrm{pH}$ and $\mathrm{Ca}$ retention. After additions of $\mathrm{CaCl}_{2}$ and $\mathrm{NaHCO}_{3}$ ceased, Ca was shown to desorb slowly from exchange sites. Over the 2-month experiment, $\mathrm{Ca}$ retention on the exchange sites within the stream channel was estimated to be between 0.5 and $2.5 \mathrm{eq} \mathrm{Ca} / \mathrm{m}^{2}$ channel area (Hall et al. 2001).

As part of the Experimental Watershed Liming Study (EWLS) in the Adirondack Mountains of New York, $\mathrm{CaCO}_{3}$ was applied to both a ponded and a free flowing watershed (Driscoll et al. 1996). After 2 years, the free flowing watershed had delivered $2.2 \%$ of the $\mathrm{CaCO}_{3}$ to the lake, while the ponded catchment had delivered 60\% (Cirmo and Driscoll 1996). The continuous wetting of the $\mathrm{CaCO}_{3}$ in the ponded watershed was the primary explanation for faster dissolution. A significant amount of $\mathrm{Ca}$ had also adsorbed onto organic matter within wetted areas in the ponded watershed. The exchangeable fraction of $\mathrm{Ca}$ on sphagnum moss within the treatment area was approximately 10 times that measured in an adjacent untreated plot and accounted for nearly $8 \%$ of the total $\mathrm{CaCO}_{3}$ applied (Cirmo and Driscoll 1996). A concurrent study examined the behavior of Ca along a $3 \mathrm{~km}$ stream reach draining the watershed area. Before the addition of $\mathrm{CaCO}_{3}, \mathrm{Ca}$ concentrations were constant along the length of the stream reach, with a value of 120 $\mu$ eq/L. After the $\mathrm{CaCO}_{3}$ addition, streamwater $\mathrm{pH}$ decreased from 6.7 to 5.7 along the stream reach, with a corresponding 50-65\% reduction in the Ca concentration. While most elements behaved conservatively, Ca was apparently partially removed through adsorption onto materials in the streambed.

\section{Laboratory dissolution experiments}

Wollastonite dissolution rates have been measured in several studies using fluidized bed reactors (Rimstidt and Dove 1986; Weissbart and Rimstidt 2000; Xie and Walther 1994). Most experimental work has been conducted on crushed, sieved, and alcohol washed wollastonite grains in the 75 to $250 \mu \mathrm{m}$ size range, with BET surface areas between 0.133 and $0.302 \mathrm{~m}^{2} / \mathrm{g}$ (Rimstidt and Dove 1986; Weissbart and Rimstidt 2000; Xie and Walther 1994). Rates measured using these techniques range from $5.0 \times 10^{-13}$ to $1.6 \times 10^{-12} \mathrm{~mol} \mathrm{Ca} / \mathrm{cm}^{2} / \mathrm{s}$ (Figure 2). While some results initially suggested that the dissolution rate is $\mathrm{pH}$ dependant (Rimstidt and Dove 1986; Xie and Walther 1994), later experiments conducted over a broad range of 


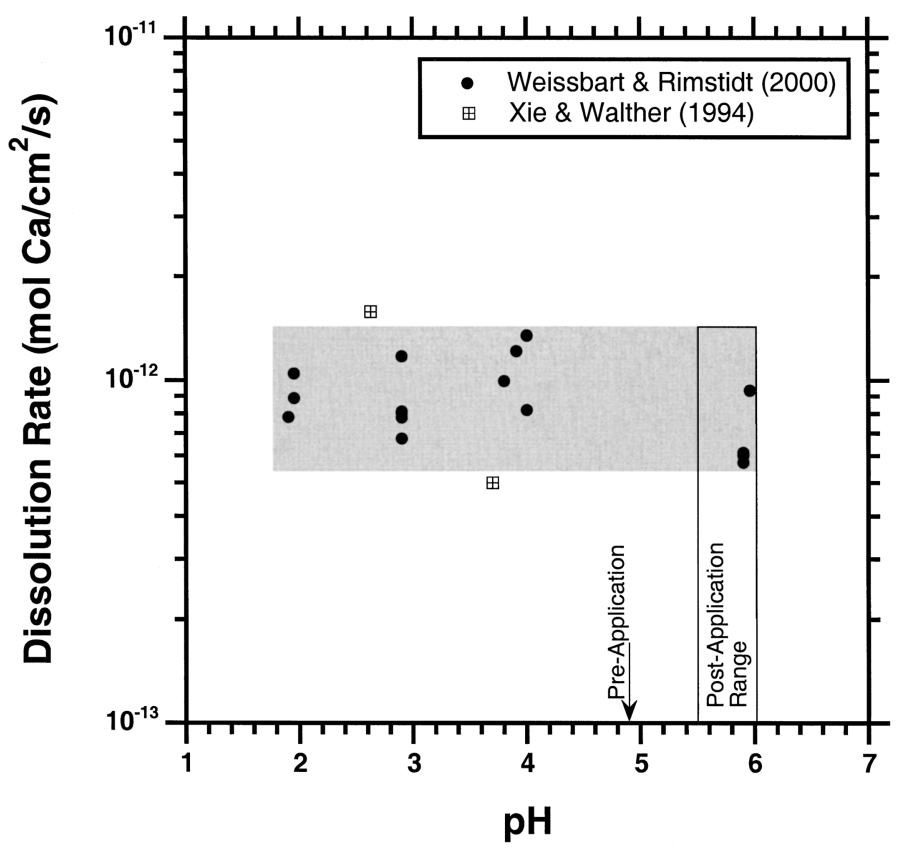

Figure 2. Wollastonite dissolution rates measured in laboratory experiments (Weissbart and Rimstidt 2000; Xie and Walther 1994). The gray box delineates the range of dissolution rates $\left(6 \times 10^{-13}\right.$ to $1.5 \times$ $10^{-12} \mathrm{~mol} \mathrm{Ca} / \mathrm{cm}^{2} / \mathrm{s}$ ) from laboratory experiments. Arrows and a box on the $\mathrm{x}$-axis indicate the $\mathrm{pH}$ values of the W-1 stream at Hubbard Brook.

$\mathrm{pH}$ values ( $\mathrm{pH} 2-\mathrm{pH}$ 6) demonstrated that the dissolution rate is not dependent on $\mathrm{pH}$ (Weissbart and Rimstidt 2000). The $\mathrm{pH}$ of the W-1 stream at the HBEF is within the range of $\mathrm{pH}$ values studied in laboratory experiments, with a pre-application $\mathrm{pH}$ value of $\sim 4.95$ and post-application $\mathrm{pH}$ values of $\sim 5.5$ to $\sim 6.0$. Dissolution rates for wollastonite have been shown to be temperature dependent, with the rate at $40{ }^{\circ} \mathrm{C}$ approximately $2-3$ times faster than at $23.5^{\circ} \mathrm{C}$ (Rimstidt and Dove 1986). Dissolution rates calculated using the average annual streamwater temperature and the activation energy range from $1.6 \times 10^{-13}$ to $4.2 \times 10^{-13} \mathrm{~mol} \mathrm{Ca} / \mathrm{cm}^{2} / \mathrm{s}$.

Wollastonite has been observed to dissolve incongruently in laboratory experiments, with Ca released preferentially relative to $\mathrm{Si}$, leading to the development of a leached layer (Weissbart and Rimstidt 2000; Xie and Walther 1994). The development of the leached layer results in increases in BET measured surface area and decreases in release rates of both $\mathrm{Ca}$ and Si (Weissbart and Rimstidt 2000). The morphology of this leached layer surface has been investigated and confirmed through interferometry (Grove et al. 2000) and high-resolution transmission electron microscopy (Banfield et al. 1995). 


\section{Methods}

Wollastonite was mined from the No. 4 Quarry of the Valentine Mine in the northwestern Adirondack Mountains of New York, a skarn deposit related to the Proterozoic Diana Complex metasyenite (Gerdes and Valley 1994). The wollastonite was crushed to a mean grain size of $16 \mu \mathrm{m}$ and formed into 1 to $3 \mathrm{~mm}$ pellets using a water-soluble lignin sulfonate binder. The specific surface area of the wollastonite was measured using gas adsorption (BET) techniques and found to be $1.6 \mathrm{~m}^{2} / \mathrm{g}$.

Streamwater samples were collected $10 \mathrm{~m}$ above the gauging weir at the base of $\mathrm{W} 1$ in acid-cleaned bottles. Water from lysimeters was pumped using a peristaltic pump, syringe filtered through a $0.45 \mu \mathrm{m}$ polypropylene membrane, and stored in acid cleaned bottles. Elemental analysis of all water samples was conducted using Inductively Coupled Plasma Optical Emission Spectrometry (ICP-OES), Inductively Coupled Plasma Mass Spectrometry (ICP-MS) and ion chromatography (IC). The ICP-OES (PE-3300DV, Perkin Elmer, Norwalk, CT) and ICP-MS (ELEMENT, Finnigan, Bremen, Germany) instruments were calibrated using custom multielement standards that were carefully matched to the streamwater composition. Working standards were prepared from concentrated stock solutions the day of analysis. Calibration curves consistently had $\mathrm{R}^{2}$ values greater than 0.9999 and were linear over the calibrated range. Secondary standards (NIST-1643d) at full strength, and diluted 1:10 to match stream chemistry were analyzed before and after each sequence of samples. Measured values agreed with certified values to within 5\%.

Strontium isotope ratios were determined by Thermal Ionization Mass Spectrometry (TIMS). A volume of water containing between 100-300 ng of Sr was evaporated and digested in a single drop of concentrated ultrapure $\mathrm{HNO}_{3}$. Samples were evaporated again, redissolved in $3 \mathrm{M} \mathrm{HNO}_{3}$, and the $\mathrm{Sr}$ was separated using a $\mathrm{Sr}$ specific resin (Eichrom, Darien, IL, USA). Approximately $75 \mathrm{ng}$ of $\mathrm{Sr}$ was evaporated, redissolved in $0.3 \mathrm{M} \mathrm{H}_{3} \mathrm{PO}_{4}$ and loaded onto tungsten single filaments with $\mathrm{Ta}_{2} \mathrm{O}_{5}$ powder. The strontium isotopic composition was analyzed using a TIMS (MAT-262, Finnigan, Bremen, Germany) operated in static mode with the background measured at half mass. The ${ }^{87} \mathrm{Sr} /{ }^{86} \mathrm{Sr}$ ratios were corrected for instrumental fractionation by normalizing the ${ }^{86} \mathrm{Sr} /{ }^{88} \mathrm{Sr}$ ratio to 0.1194 . Repeated measurements of NBS-987 resulted in a mean ${ }^{87} \mathrm{Sr} /{ }^{86} \mathrm{Sr}$ value of $0.710252 \pm 0.000013(\mathrm{n}=161)$.

\section{Results}

\section{Initial conditions}

To characterize the chemical variability of the streamwater prior to wollastonite application, stream samples were collected weekly and analyzed for one year prior to the date of application (Figures 3a-3g). Sixteen stream samples were also collected during precipitation events to measure solute variability during fluctuations in hydrologic discharge. During the one-year period, the ${ }^{87} \mathrm{Sr} /{ }^{86} \mathrm{Sr}$ isotopic composition 
of streamwater ranged from 0.72014 to $0.72060,(\bar{x}=0.72032 \pm 0.00006,1 \sigma)$, and $\mathrm{Sr}$ concentrations ranged from 2.37 to $7.30 \mu \mathrm{g} / \mathrm{L}(\bar{x}=5.76 \pm 0.49 \mu \mathrm{g} / \mathrm{L}, 1 \sigma)$.

Calcium concentrations ranged from 0.71 to $1.06 \mathrm{mg} / \mathrm{L}(\bar{x}=0.87 \pm 0.086 \mathrm{mg} / \mathrm{L}$, $1 \sigma)$, Na concentrations ranged from 0.59 to $1.24 \mathrm{mg} / \mathrm{L}(\bar{x}=0.87 \pm 0.12 \mathrm{mg} / \mathrm{L}, 1 \sigma)$, and $\mathrm{Si}$ concentrations exhibited the largest variability, with concentrations ranging from 1.2 to $2.5 \mathrm{mg} / \mathrm{L}(\bar{x}=2.1 \pm 0.26 \mathrm{mg} / \mathrm{L}, 1 \sigma)$ during the pre-application year. The concentrations of $\mathrm{Ca}$ and $\mathrm{Na}$ have been measured weekly for 36 years, and $\mathrm{Si}$ concentrations for 29 years as part of the Hubbard Brook Ecosystem Study (Likens and Bormann 1995). The one-year pre-application values are statistically identical to the long-term record for all elements except $\mathrm{Ca}$ (Table 1). Calcium concentrations had decreased over the long-term study (Likens et al. 1998) and were approximately $0.872 \mathrm{mg} / \mathrm{L}$ immediately prior to the application, compared to the 36 -year mean of $1.40 \mathrm{mg} / \mathrm{L}$. For consistency, all calculations of changes in streamwater chemistry due to the wollastonite were based on the one-year pre-application values.

\section{Wollastonite application}

The chemical composition of the applied wollastonite is summarized in Table 2. The wollastonite has a considerably lower ${ }^{87} \mathrm{Sr} /{ }^{86} \mathrm{Sr}$ ratio and a higher $\mathrm{Ca} / \mathrm{Sr}$ ratio than the pre-application stream values. Solutes from wollastonite dissolution, when mixed with the streamwater, should decrease the ${ }^{87} \mathrm{Sr} /{ }^{86} \mathrm{Sr}$ ratio and increase the $\mathrm{Ca} / \mathrm{Sr}$ ratio. The wollastonite was applied at a rate of 4.6 metric tons/ha (1.6 metric tons $\mathrm{Ca} / \mathrm{ha}$ ) over the entire watershed using a helicopter equipped with a 1-ton motorized spreader and a GPS navigation system to ensure an even application rate. To determine the amount of wollastonite that had been deposited into the stream channel, we surveyed the channel area by measuring the bank to bank width at 5-m intervals along the length of the stream. The total streambed area was calculated to be $1,804 \mathrm{~m}^{2}$, comprising $1.53 \%$ of the total 11.8 ha watershed. Using this area and the application rate of $350 \mathrm{~g} / \mathrm{m}^{2}$, approximately $631 \mathrm{~kg}$ of the total 55 tons of wollastonite is estimated to have fallen directly into the stream channel area during the application.

More than $98 \%$ of the wollastonite was added to the forest floor rather than the streambed, and the possible influence of this wollastonite through shallow groundwater flowpaths was considered. Measurements of ${ }^{87} \mathrm{Sr} /{ }^{86} \mathrm{Sr}$ and $\mathrm{Ca} / \mathrm{Sr}$ in water collected from lysimeters placed in the $\mathrm{Oa}, \mathrm{Bh}$, and $\mathrm{Bs}$ soil horizons in 3 locations throughout the watershed indicate that $\mathrm{Ca}$ and $\mathrm{Sr}$ derived from wollastonite dissolution was not substantially transported beyond the upper soil horizons during the first year after the application. Groundwater has been shown to contribute the majority of water to streams, even during storm events (Kendall and MacDonnell 1998), and solutes from wollastonite would first have to be dissolved and transported in soil water to reach groundwater. Therefore, all calculations assume that the streamwater response to the experimental treatment is predominantly due to 


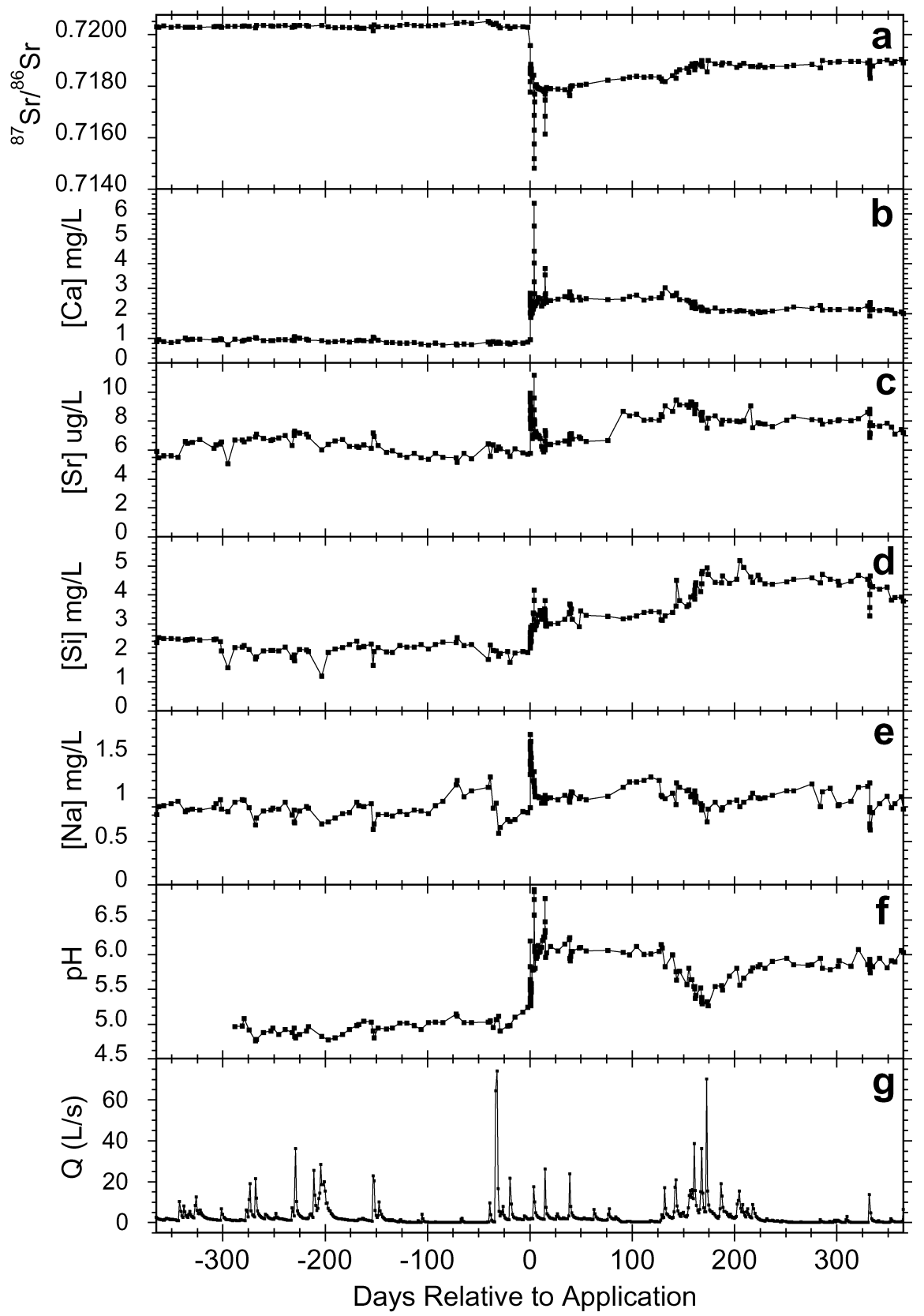

Figure 3. Chemical analysis and discharge of Watershed 1 streamwater: (a) ${ }^{87} \mathrm{Sr} /{ }^{86} \mathrm{Sr}$, (b) [Ca], (c) [Sr], (d) $[\mathrm{Si}]$, (e) $[\mathrm{Na}]$, (f) $\mathrm{pH},(\mathrm{g})$ Discharge $(\mathrm{Q}, 1 / \mathrm{s})$. Time is in days relative to the wollastonite application date of October 19, 1999. 
Table 1. Pre-application chemical composition of streamwater in W1. Variability is expressed as $1 \sigma$.

\begin{tabular}{lll}
\hline & 36 year pre-application & 1 year pre-application \\
\hline${ }^{\mathbf{8}} \mathbf{S r} /{ }^{\mathbf{8}} \mathbf{S r}$ & N/A & $0.72032 \pm .00006$ \\
$\mathbf{C a}$ & $1.40 \pm 0.35 \mathrm{mg} / \mathrm{L}$ & $0.872 \pm .086 \mathrm{mg} / \mathrm{L}$ \\
$\mathbf{S r}$ & N/A & $6.23 \pm 0.57 \mu \mathrm{g} / \mathrm{L}$ \\
$\mathbf{N a}$ & $0.82 \pm 0.16 \mathrm{mg} / \mathrm{L}$ & $0.86 \pm 0.12 \mathrm{mg} / \mathrm{L}$ \\
$\mathbf{S i}$ & $2.00 \pm 0.21 \mathrm{mg} / \mathrm{L}$ & $2.13 \pm 0.26 \mathrm{mg} / \mathrm{L}$ \\
$\mathbf{C a} / \mathbf{S r}(\mathbf{m o l})$ & N/A & 306 \\
\hline
\end{tabular}

Table 2. Wollastonite pellet composition. Major element oxides are listed as weight percent. LOI is loss on ignition at $800{ }^{\circ} \mathrm{C}$ to constant mass.

\begin{tabular}{|c|c|}
\hline & Wollastonite \\
\hline${ }^{87} \mathrm{Sr} /{ }^{86} \mathrm{Sr}$ & 0.70554 \\
\hline $\mathrm{CaO}$ & $41.6 \%$ \\
\hline $\mathrm{SiO}_{2}$ & $48.3 \%$ \\
\hline $\mathrm{Ca} / \mathrm{Sr}$ (mol) & 2,900 \\
\hline MgO & $1.82 \%$ \\
\hline $\mathrm{Al}_{2} \mathrm{O}_{3}$ & $0.49 \%$ \\
\hline $\mathrm{Na}_{2} \mathrm{O}$ & $0.25 \%$ \\
\hline $\mathbf{K}_{2} \mathbf{O}$ & $0.21 \%$ \\
\hline LOI & $7.3 \%$ \\
\hline Mean particle size & $16 \mu \mathrm{m}$ \\
\hline BET surface area & $1.6 \mathrm{~m}^{2} / \mathrm{g}$ \\
\hline
\end{tabular}

wollastonite dissolving in the streambed without significant contributions from the wollastonite deposited on the land surface.

The potential for suspended transport of particulate wollastonite from the watershed was also considered. To measure particulate export, streamwater samples were collected and filtered throughout the experiment at various discharges ranging from low flow $(\min =0.025 \mathrm{~L} / \mathrm{s})$ to stormflow $(\max =69 \mathrm{~L} / \mathrm{s})$. Particulates retained on the filters were then digested and analyzed, with detectable Ca found in 6 of 54 samples. Two of the six samples were collected on the first day of application, and the remaining four were collected during stormflow events on days 4, 15, and 161 . During stormflow events, all filters with detectable $\mathrm{Ca}$ also contained $\mathrm{Al}$ and $\mathrm{Mg}$, indicating some transport of minerals other than wollastonite. If all of the $\mathrm{Ca}$ were attributable to wollastonite transport, the two samples obtained on the first day of application would represent particulate Ca concentrations of 44 and $80 \mu \mathrm{g} / \mathrm{L}$. This would correspond to approximately $3.3 \%$ and $6.1 \%$ of the total dissolved Ca from wollastonite during the same period. Similarly for the stormflow periods, particulate $\mathrm{Ca}$ concentrations of 136,119 , and $80 \mu \mathrm{g} / \mathrm{L}$ on days 4,15 , and 161 would correspond to $7.7 \%, 7.6 \%$, and $6.9 \%$ of the total Ca concentrations from wollastonite for the same time periods. Analysis of particulate $\mathrm{Al}$ and $\mathrm{Mg}$ on the same filters 
indicated $\mathrm{Al}$ concentrations of 40,35, and $60 \mu \mathrm{g} / \mathrm{L}$ and $\mathrm{Mg}$ concentrations of 8, 3.5, and $7 \mu \mathrm{g} / \mathrm{L}$, suggesting that a significant portion of the exported particulate $\mathrm{Ca}$ during storm events may not have been from wollastonite. In all cases, particulate $\mathrm{Ca}$ concentrations represent a maximum of $10 \%$ of the total dissolved concentration of Ca from wollastonite and for only limited time periods, and thus can be disregarded for the purposes of this investigation.

\section{Stream response to wollastonite application}

Upon application of the wollastonite to W1 on October 19,1999 , the ${ }^{87} \mathrm{Sr} /{ }^{86} \mathrm{Sr}$ isotopic composition and $\mathrm{Ca}$ concentration of stream water changed markedly, reaching the most extreme values of 0.71481 and $6.43 \mathrm{mg} / \mathrm{L}$ during the first precipitation event four days after the application (Figure 3a, 3b). Within a few weeks, the stream chemistry stabilized to a ${ }^{87} \mathrm{Sr} /{ }^{86} \mathrm{Sr}$ isotopic ratio of $\sim 0.71818$ and Ca concentration of $\sim 2.6 \mathrm{mg} / \mathrm{L}$.

The concentration of $\mathrm{Sr}$ in stream water increased immediately, reaching a maximum value of $11.2 \mu \mathrm{g} / \mathrm{L}$ during a precipitation event 4 days after the application date (Figure 3c). Following the event, $\mathrm{Sr}$ concentrations returned to nearly pre-application values. The concentration of $\mathrm{Si}$ in the stream increased to a maximum value of $4.17 \mathrm{mg} / \mathrm{L}$ immediately after the application date (Figure $3 \mathrm{~d}$ ). This peak was followed by a twelve-month period with moderately stable concentrations, with an average value of $\sim 3.4 \mathrm{mg} / \mathrm{L}$. The concentration of $\mathrm{Na}$ in stream water increased after the application, reaching a maximum value of $1.73 \mathrm{mg} / \mathrm{L}$ on the first day of the application (Figure 3e). After 4 days, Na concentrations returned to pre-application values. The $\mathrm{Na}$ is attributed to the immediate dissolution of the sodium lignin-sulfonate binder used to pelletize the wollastonite, indicating disaggregation of these pellets in the stream channel. Streamwater $\mathrm{pH}$ increased following the application, reaching a maximum value of 6.93 during a precipitation event four days after the application and then stabilized at an average value of $\sim 6.0$ after 21 days (Figure 3f).

Precipitation events that occurred 1, 4, and 15 days after the application resulted in pulses of increased $\mathrm{Ca}$ and $\mathrm{Si}$ concentrations, and corresponding decreases in the ${ }^{87} \mathrm{Sr} /{ }^{86} \mathrm{Sr}$ ratio (Figure 3g). After two months, elevated discharge related to precipitation events had either no effect, or only slightly reduced the $\mathrm{Ca}$ and Si concentrations.

\section{Discussion}

Initial conditions \& immediate stream response

The measurement of stream chemistry for the year prior to the wollastonite application confirmed that the strontium isotopic composition and $\mathrm{Ca}$ concentration of this stream were extremely stable, and that the effects of small additions of $\mathrm{Ca}$ and 
$\mathrm{Sr}$ bearing material could be distinguished from stream background values. Also important is the observation that the one year of pre-application data are not statistically different from the 36-year archive of stream chemistry, except for Ca. These data suggest that we have an accurate measure of the pre-application conditions with which to compare to the post-application results. The pulses of increased $\mathrm{Ca}$ and $\mathrm{Si}$ concentrations on days 1, 4 and 15 are most likely due to the dissolution of the finest particle sizes within the stream banks that were wetted as the water level rose during these high flow periods. Following the initial dissolution of this fine fraction, concentrations appeared to stabilize for the remainder of the experiment. This accelerated dissolution rate early in the experiment is similar to observations made in laboratory dissolution experiments.

\section{Apportioning solutes using Sr isotopes}

The dissolution of wollastonite in the stream was examined using a two-component isotope solute mixing model. A strontium isotope mixing diagram was constructed with the pre-application stream background and wollastonite endmembers plotted and connected by a thick gray line (Figure 4). Stream chemistry data were plotted as a series of connected points in chronological order. Mixing appears to have been linear between the two endmembers, with two large excursions toward the wollastonite endmember coinciding with increases in $\mathrm{Ca}$ and decreases in ${ }^{87} \mathrm{Sr} /{ }^{86} \mathrm{Sr}$ during post-application precipitation events. The strontium isotopic composition of the streamwater was the result of the contribution of $\mathrm{Sr}$ from wollastonite dissolution $\left(\mathrm{X}_{\mathrm{Sr}}\right)$ mixed with the background streamwater $\mathrm{Sr}$, which is described by the following equation:

$$
\left(\frac{{ }^{87} S r}{{ }^{86} S r}\right)_{\text {Stream }}=\left(X_{S r}\right)\left(\frac{{ }^{87} S r}{{ }^{86} S r}\right)_{\text {Wollastonite }}+\left(1-X_{S r}\right)\left(\frac{{ }^{87} S r}{{ }^{86} S r}\right)_{B k g n d}
$$

Although the rigorous solution for this mixing relation necessitates the use of ${ }^{87} \mathrm{Sr} / \mathrm{Sr}_{\text {total }}$, substituting the ${ }^{87} \mathrm{Sr} /{ }^{86} \mathrm{Sr}$ ratio does not significantly alter the results when endmember isotopic compositions are within $10 \%$, as was the case in this study. Solving for $\mathrm{X}_{\mathrm{Sr}}$, the fraction of streamwater $\mathrm{Sr}$ that was attributable to wollastonite, yields the equation:

$$
X_{S r}=\left[\frac{\left(\frac{{ }^{87} S r}{{ }^{86} S r}\right)_{\text {Stream }}-\left(\frac{{ }^{87} S r}{{ }^{86} S r}\right)_{B k g n d}}{\left(\frac{{ }^{87} S r}{{ }^{86} S r}\right)_{\text {Wollastonite }}-\left(\frac{{ }^{87} S r}{{ }^{86} S r}\right)_{B k g n d}}\right]
$$

Using $\mathrm{Sr}$ as a proxy for $\mathrm{Ca}$, the mole fraction of $\mathrm{Ca}$ in the stream water that was 


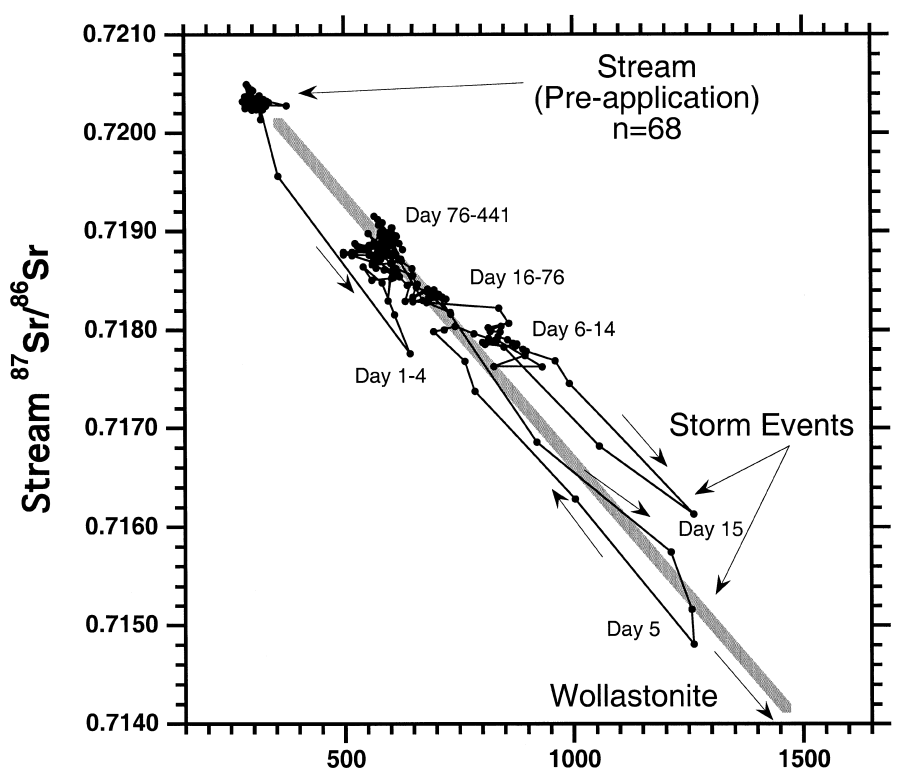

Stream Ca/Sr $(\mathrm{mol} / \mathrm{mol})$

Figure 4. Isotope mixing diagram. One year of pre-application data are plotted as the streamwater background endmember. The wollastonite endmember from Table 2 plots below the x-axis. The gray line is a linear mixing calculation between these two endmembers. The two large excursions towards the wollastonite endmember coincide with storm events immediately following the application. Samples were taken hourly during storm events, daily for the first 17 days, and weekly thereafter.

derived from wollastonite dissolution is given by:

$X_{C a}=\left[\frac{\left(\left(\frac{{ }^{87} S r}{{ }^{86} S r}\right)_{\text {Stream }}-\left(\frac{{ }^{87} S r}{{ }^{86} S r}\right)_{{ }_{B k g n d}}\right)\left(\frac{S r}{C a}\right)^{B k g n d}}{\left(\left(\frac{{ }^{87} S r}{{ }^{86} S r}\right)_{\text {Srream }}-\left(\frac{{ }^{87} S r}{{ }^{86} S r}\right)_{B k g n d}\right)\left(\frac{S r}{C a}\right)^{B k g n d}+\left(\left(\frac{{ }^{87} S r}{{ }^{86} S r}\right)_{\text {Wollastonite }}-\left(\frac{{ }^{87} S r}{{ }^{86} S r}\right)_{\text {Srream }}\right)\left(\frac{S r}{C a}\right)_{\text {Wollastonite }}}\right]$

where $\mathrm{Sr} / \mathrm{Ca}$ is the ratio of $\mathrm{Sr}$ to $\mathrm{Ca}$ in each endmember. This factor $\left(\mathrm{X}_{\mathrm{Ca}}\right)$ is plotted as a function of stream water ${ }^{87} \mathrm{Sr} /{ }^{86} \mathrm{Sr}$ and stream water $\mathrm{Ca} / \mathrm{Sr}$ in Figure 5 , and then multiplied by the stream water $\mathrm{Ca}$ concentration to apportion the solutes to either the stream background or the dissolution of wollastonite (Figures 6b, 6c).

\section{Calculation of wollastonite dissolution rate}

In laboratory experiments, mineral dissolution rates $\left(r_{i}\right)$ are generally calculated using the following equation:

$$
r_{i}=\left(\frac{r_{f} \times\left([m]_{(i n)}-[m]_{(o u t)}\right)}{(\text { mass }) \times A_{s p}}\right)
$$




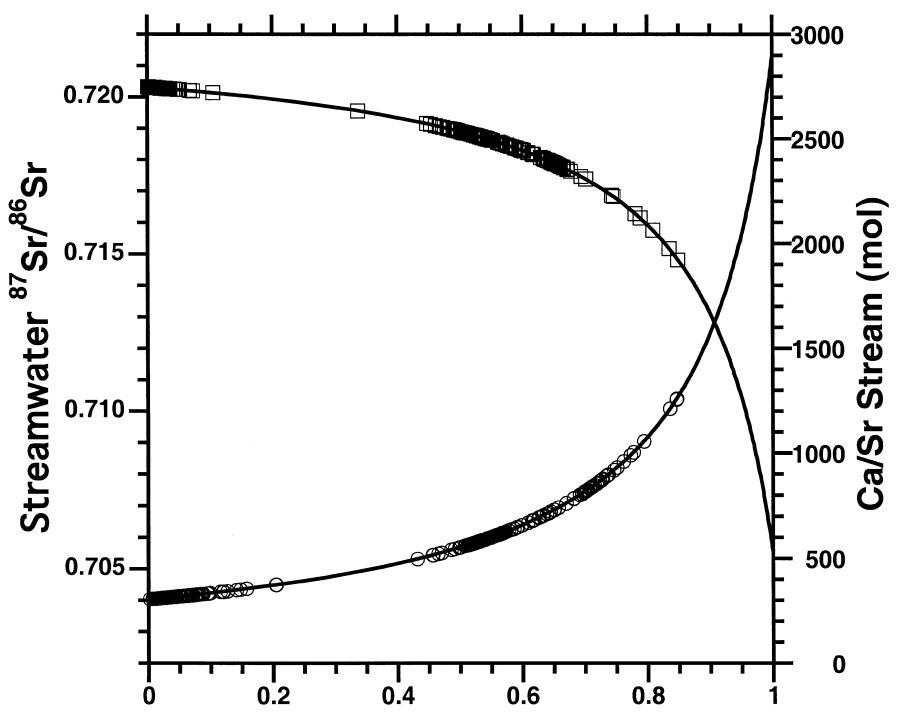

Fraction of $\mathrm{Ca}$ from Wollastonite (xCa)

Figure 5. Mixing diagram showing ${ }^{87} \mathrm{Sr} /{ }^{86} \mathrm{Sr}$ and $\mathrm{Ca} / \mathrm{Sr}$ of streamwater as a function of the proportion of Ca from wollastonite $\left(\mathrm{X}_{\mathrm{Ca}}\right)$. Solid lines illustrate continuous calculated mixing between the background stream and wollastonite endmembers, with $\mathrm{Ca} / \mathrm{Sr}$ (circles) and ${ }^{87} \mathrm{Sr} /{ }^{86} \mathrm{Sr}$ (squares) plotted for individual streamwater samples.

where $r_{f}$ is the solution flow rate and $\left([\mathrm{m}]_{(\mathrm{in})}-[\mathrm{m}]_{(\mathrm{out})}\right)$ is the change in the solute concentrations through a column or reactor. These two variables, taken together, define the release rate for the reaction. This release rate is then divided by the total surface area, given by the product of the mass of the reacting substance and its specific surface area, $A_{\mathrm{sp}}$. We have treated the stream as a reactor, and thus, the arrangement of all parameters is similar, though larger in scale. The release rate, or flux of Ca from wollastonite dissolution $\left(\mathrm{J}_{\mathrm{Ca}}\right)$ is given by:

$$
J_{\mathrm{Ca}}=X_{\mathrm{Ca}} \times[\mathrm{Ca}]_{\text {Stream }} \times J_{\mathrm{H}_{2} \mathrm{O}}
$$

where $\mathrm{J}_{\mathrm{H}_{2} \mathrm{O}}$ was the flux of water measured at the gauging weir. The Ca flux was then converted to a mass of exported wollastonite by dividing by the amount of $\mathrm{Ca}$ per unit of wollastonite $(0.345 \mathrm{~g} / \mathrm{g})$. This wollastonite flux was then subtracted from the initial quantity of wollastonite to determine how much remained in the streambed (Figure 6d). Starting from the initial quantity of wollastonite deposited in the stream channel of $631 \mathrm{~kg}$, we calculate that an amount of $\mathrm{Ca}$ equivalent to approximately $230 \mathrm{~kg}$ of wollastonite remained in the stream channel after 365 days.

An apparent dissolution rate (ADR) for wollastonite for each water sample analyzed was then calculated by dividing this $\mathrm{Ca}$ flux $\left(\mathrm{J}_{\mathrm{Ca}}\right)$ by the mineral surface area 


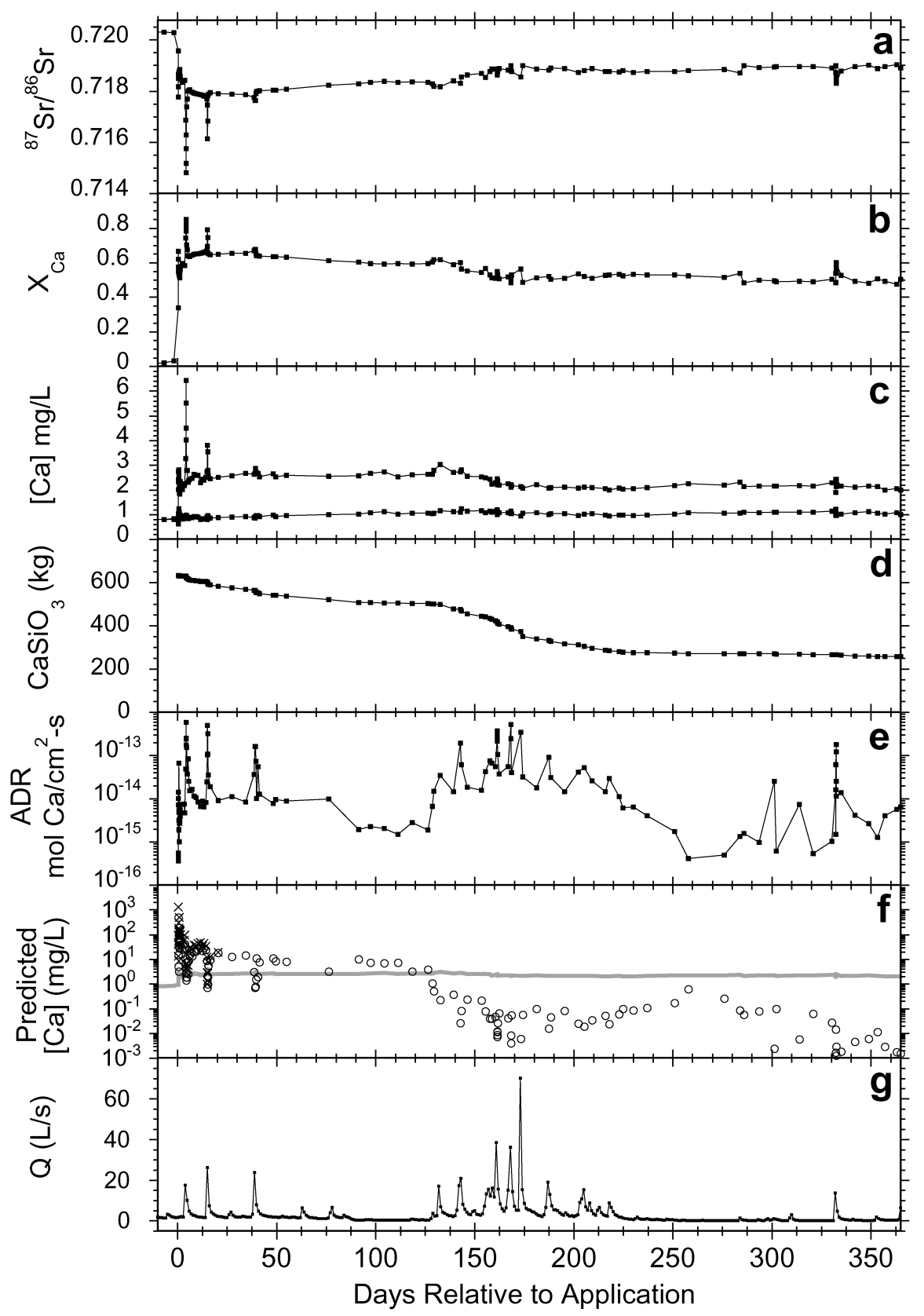

Figure 6. Streamwater response to wollastonite application. (a) Streamwater ${ }^{87} \mathrm{Sr} /{ }^{86} \mathrm{Sr}$, (b) the fraction of $\mathrm{Ca}$ attributable to wollastonite dissolution, (c) the concentration of $\mathrm{Ca}$ in streamwater (upper line), and the calculated background concentration of $\mathrm{Ca}$ determined by $\mathrm{Sr}$ isotopes (lower line) (Note: the difference between these curves is Ca derived from wollastonite dissolution), (d) the amount of $\mathrm{CaSiO}_{3}$ remaining in the watershed (initial conditions - export), (e) the calculated apparent dissolution rate (ADR) of wollastonite, (f) the predicted streamwater Ca concentration at a dissolution rate of $4.2 \times$ $10^{-13} \mathrm{~mol} \mathrm{Ca} / \mathrm{cm}^{2} / \mathrm{s}(\times)$ and, $1.6 \times 10^{-13} \mathrm{~mol} \mathrm{Ca} / \mathrm{cm}^{2} / \mathrm{s}(\bigcirc)$, and $(\mathrm{g})$ stream discharge $(\mathrm{Q}$, in $\mathrm{L} / \mathrm{s})$ following the application of wollastonite. 
of the material that was actively dissolving in the stream (Figure 6e).

$$
A D R=\left(\frac{J_{C a}}{\text { mass } \times A_{s p}}\right)
$$

Calculated ADRs varied by nearly four orders of magnitude during the year-long study; which is far beyond the magnitude of variation observed during laboratory experiments. Typical variability ranges from factors of $2-3$ within studies, to about factors of 2-20 between different studies (e.g., Swoboda Colberg and Drever (1993) and Weissbart and Rimstidt (2000), Xie and Walther (1994)). To determine the cause of the variability observed in our study, we explored the variability in parameters used to calculate the dissolution rate: mineral surface area, hydrologic flux, and streamwater $\mathrm{Ca}$ concentration.

The calculation of a dissolution rate uses an estimate of mineral surface area, which is equal to the total mass of reacting material multiplied by the specific surface area per unit mass of material. In this experiment, nearly $50 \%$ of the total mass of wollastonite was exported in solution via the stream. To account for this export, the total reactive mass used in the calculation was reduced during each period of the experiment by an amount equal to the wollastonite export during the prior period. This is a correction that is not necessary in laboratory experiments, since less than $5 \%$ of the material is usually dissolved by the end of the experimental run. If this reduction in mass were not considered in this calculation, it would result in a rate approximately two times slower than the present calculations. The specific surface area used in calculations was measured before the application, which is the same convention employed in laboratory experiments. During the course of laboratory experiments, specific surface area of wollastonite has been observed to increase by a factor of $2-100$ over the starting material. This increase in mineral surface area is most likely related to the thickening of the leached layer, which also results in a decrease in release rate. The convention of using the initial specific surface area might be expected to influence the rate calculations from this study and laboratory experiments equally, and should not cause significant discrepancies between dissolution rates. Additionally, changes in the specific surface area and mass of dissolving wollastonite would affect the calculated dissolution rates gradually during the experiment, and thus could not explain the complex pattern of shortperiod variations that is observed.

The two remaining parameters used in the calculation of the dissolution rate are the hydrologic flow rate, and the stream $\mathrm{Ca}$ concentration. The interplay between these two variables is critical in laboratory experiments. The behavior of systems far from equilibrium is such that an increase in flow rate results in a coincident decrease in solute concentration, maintaining a constant release rate. During this study, stream discharge fluctuated from 0.03 to $120 \mathrm{~L} / \mathrm{s}$, with little or no corresponding change in the stream $\mathrm{Ca}$ concentration. This relation might be expected if streamwater $\mathrm{Ca}$ and $\mathrm{Si}$ concentrations were close to saturation with wollastonite or some other solid mineral phase. However, the most concentrated streamwater sam- 
ple measured in this study is highly undersaturated with respect to wollastonite, with a saturation index (SI, defined as $\left.\log \left(\mathrm{IAP} / \mathrm{K}_{\mathrm{sp}}\right)=-7.1\right)$. The most saturated phases are amorphous silica ( $\mathrm{SI}=0.250$ to -0.287 ).

One possible explanation for the nearly constant $\mathrm{Ca}$ concentrations observed in the stream is that the system was buffered by the cation exchange complex in the hyporheic zone in direct contact with the stream water. To consider the feasibility of this hypothesis, we used laboratory dissolution rates to predict stream $\mathrm{Ca}$ concentrations in the absence of ion exchange, and then compared them with measured stream $\mathrm{Ca}$ concentration values. For dissolution rates ranging from $1.5 \times 10^{-12}$ to 6 $\times 10^{-13} \mathrm{~mol} \mathrm{Ca} / \mathrm{cm}^{2} / \mathrm{s}$ (the full range of experimentally determined values), the streamwater $\mathrm{Ca}$ concentration is predicted using the equation:

$$
[\mathrm{Ca}]_{p}=\frac{r \times n \times A}{J_{\mathrm{H}_{2} \mathrm{O}}}
$$

where $r$ is the selected dissolution rate, $n$ is the quantity of wollastonite that is dissolving in the streambed expressed as moles of $\mathrm{Ca}$, and $\mathrm{A}$ is the total surface area. The predicted $\mathrm{Ca}$ concentrations and the measured streamwater $\mathrm{Ca}$ concentrations were compared and plotted in Figure 6f. Predicted $\mathrm{Ca}$ concentrations varied by more than a factor of 100 while measured concentrations varied by less than a factor of 1.5 .

The difference between predicted and calculated Ca concentrations may be due to the retention or loss of $\mathrm{Ca}$ from an exchangeable pool. The amount of $\mathrm{Ca}$ sequestered in this pool was investigated by multiplying the predicted $\mathrm{Ca}$ concentrations discussed above by the hydrologic flux $\left(\mathrm{J}_{\mathrm{H}_{2} \mathrm{O}}\right)$ to determine the predicted flux of $\mathrm{Ca}$ from wollastonite dissolution, and then comparing this calculated value with the measured streamwater $\mathrm{Ca}$ flux at the weir. The difference between these two fluxes was either added to or removed from the exchange pool for each time step. This calculation was performed for the two dissolution rates discussed previously that bracket all previous laboratory experiments $\left(1.6 \times 10^{-13}, 4.2 \times 10^{-13}\right.$ $\mathrm{mol} \mathrm{Ca} / \mathrm{cm}^{2} / \mathrm{s}$ ), and the rate that would explain dissolution in this system without any retention of $\mathrm{Ca}$ on exchange sites $\left(1 \times 10^{-14} \mathrm{~mol} \mathrm{Ca} / \mathrm{cm}^{2} / \mathrm{s}\right)$. The relationship between mineral dissolution rate and stream cation exchange capacity necessary to explain the stream Ca fluxes was calculated and is plotted in Figure 7a.

Before the addition of wollastonite, the Ca concentration of streamwater (and by inference, the stream bed material Ca cation exchange pool) has been steadily declining to a 36 year low (Likens et al. 1996, 1998). The addition of wollastonite and subsequent changes in stream solute concentrations would be expected to significantly perturb the streambed cation exchange complex equilibrium. Assuming that the dissolution rates obtained in laboratory experiments are reasonable estimates, the streambed exchange pool appears to have accumulated $\mathrm{Ca}$, reaching a plateau of $\sim 1.4 \mathrm{eq} \mathrm{Ca} / \mathrm{m}^{2}$ approximately 20 days after the wollastonite application. At this time, the streambed exchange pool had presumably equilibrated with the considerably higher $\mathrm{Ca}$ concentrations in the streamwater. The streambed ex- 


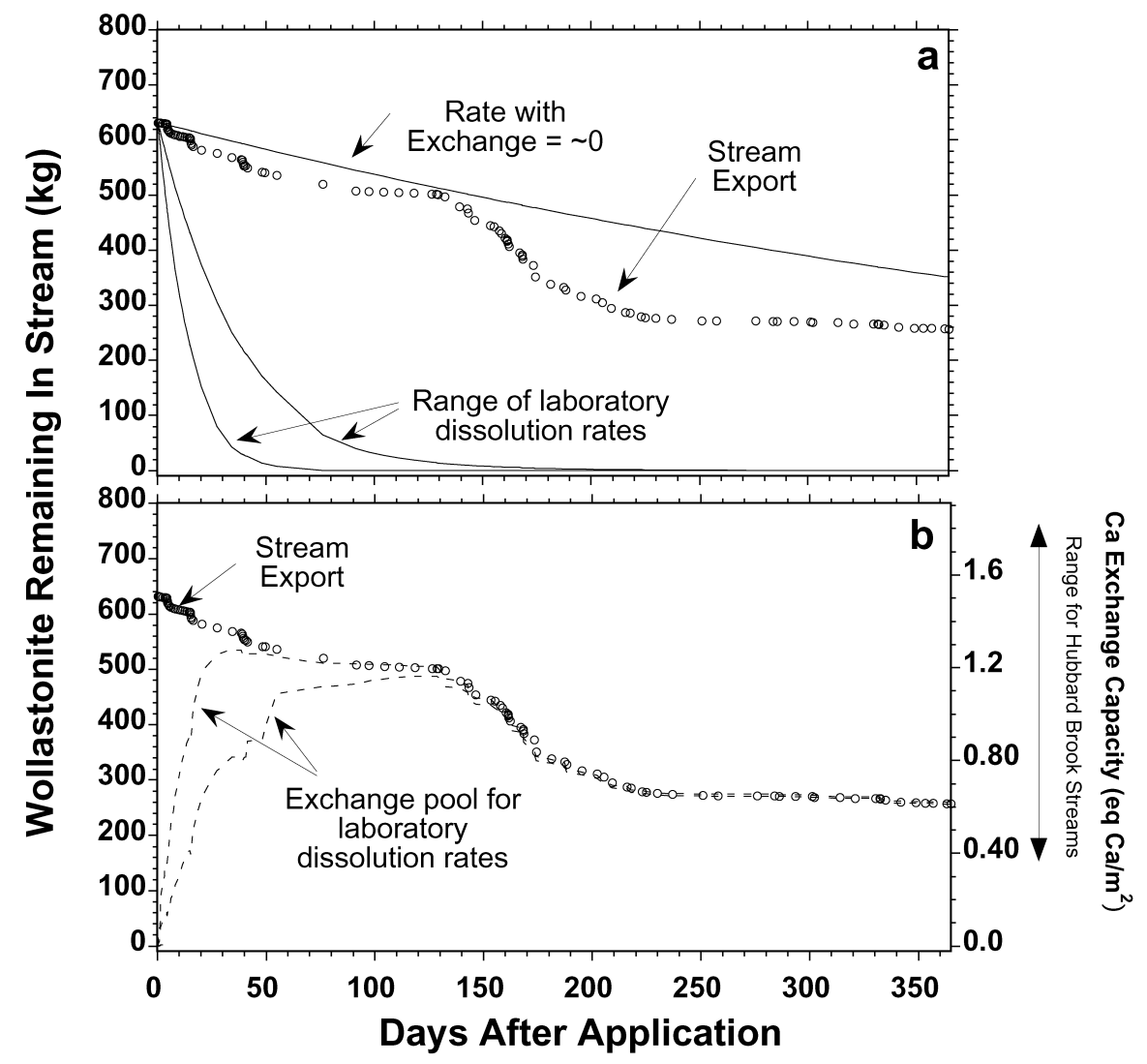

Figure 7. Wollastonite remaining in the stream channel (open circles) with time following the application of wollastonite. (a) For the dissolution rates of $4.2 \times 10^{-13} \mathrm{~mol} \mathrm{Ca} / \mathrm{cm}^{2} / \mathrm{s} 1.6 \times 10^{-13} \mathrm{~mol} \mathrm{Ca} / \mathrm{cm}^{2} / \mathrm{s}$ and $1 \times 10^{-14} \mathrm{~mol} \mathrm{Ca} / \mathrm{cm}^{2} / \mathrm{s}$ (Exchange $=0$ ), the wollastonite remaining is calculated and plotted (thin black lines). (b) Calculated $\mathrm{Ca}$ on the exchange complex (dashed lines). The wollastonite mass equivalent of the amount of $\mathrm{Ca}$ on exchange sites is given on the left Y-axis. The corresponding exchange capacity is given on the right Y-axis.

change capacity of $1.4 \mathrm{eq} \mathrm{Ca} / \mathrm{m}^{2}$ compares favorably with data obtained by Hall et al. (2001), who measured the streambed exchange capacities $200 \mathrm{~m}$ downstream of the $\mathrm{W}-1$ weir to be 0.5 to $2.5 \mathrm{eq} \mathrm{Ca} / \mathrm{m}^{2}$. Considering this exchangeable component of stream chemistry, the wollastonite dissolution rates previously measured in the laboratory can be reconciled with our observations of the stream response to the wollastonite addition.

This result provides insight into several hypotheses put forth to explain the observed differences between laboratory and field measured dissolution rates on the same silicate minerals. Weathering rates determined using field techniques have typically been between 1 and 3 orders of magnitude slower than those determined experimentally in the laboratory (Velbel 1993). Possible explanations for this discrepancy have been discussed extensively (e.g., Blum and Stillings (1995)) and in- 
clude: the dependence on solution saturation state, difficulties measuring field reactive surface area, unsaturated zone hydrology, and the influence of wetting and drying cycles. In this experiment, the system was far from equilibrium and nearly continuously wetted, much like laboratory column experiments. General agreement of the results of this field experiment with laboratory rates is therefore consistent with these rate-limiting environmental parameters providing an explanation for the discrepancy between field and laboratory measured dissolution rates.

\section{Dissolution stoichiometry}

The ratio of $\mathrm{Ca}$ to $\mathrm{Si}$ released from the wollastonite mineral structure in the W-1 stream can be illustrated in a graph of $\mathrm{Si} / \mathrm{Ca}$ vs $\mathrm{Sr} / \mathrm{Ca}$ (Figure 8). During the first few weeks of the experiment, $\mathrm{Ca}$ was released at a faster rate than $\mathrm{Si}$. The degree of preferential release of $\mathrm{Ca}$ decreased with time during the first 6 months of the experiment by which time the release was nearly stoichiometric. Data collected after $\sim 6$ months show a more rapid release of $\mathrm{Si}$ than $\mathrm{Ca}$. This difference is consistent with experimental results, which show preferential leaching of $\mathrm{Ca}$ during the initial stages of wollastonite dissolution resulting in Ca-depleted mineral surfaces (Weissbart and Rimstidt 2000). While most laboratory experiments only view the initial release of $\mathrm{Ca}$, this experiment was conducted for a long enough duration to allow the dissolution of the residual Ca-depleted wollastonite mineral phase.

\section{Conclusions}

The application of wollastonite to a forested watershed within the HBEF presents the opportunity to observe the dissolution of a well-studied silicate mineral in a natural environment. Stream Ca concentrations could be accurately attributed to either wollastonite dissolution or stream water background using the distinct ${ }^{87} \mathrm{Sr} /$ ${ }^{86} \mathrm{Sr}$ and $\mathrm{Ca} / \mathrm{Sr}$ ratios of both the background stream water and the applied wollastonite. After accounting for cation exchange within the stream channel bed materials, the dissolution rate determined in laboratory experiments is consistent with observed changes in stream chemistry as a result of the wollastonite application.

The analysis of $\mathrm{Ca}$ and $\mathrm{Si}$ from wollastonite dissolution suggests preferential release of $\mathrm{Ca}$ over $\mathrm{Si}$ in the initial stages of weathering, followed by a period of stoichiometric release, and finally a period of preferential Si release. This observation supports previous laboratory experimental results that demonstrated the development of a Ca-depleted surface layer during initial stages of mineral dissolution.

The proportion of $\mathrm{Ca}$ from wollastonite dissolution in any ecosystem component can be quantified using the ${ }^{87} \mathrm{Sr} /{ }^{86} \mathrm{Sr}$ and $\mathrm{Ca} / \mathrm{Sr}$ ratios. Thus, the movement of Ca released by wollastonite dissolution can be traced through the aquatic and terrestrial ecosystems, allowing us to study the pathways and rates of $\mathrm{Ca}$ transfer. 


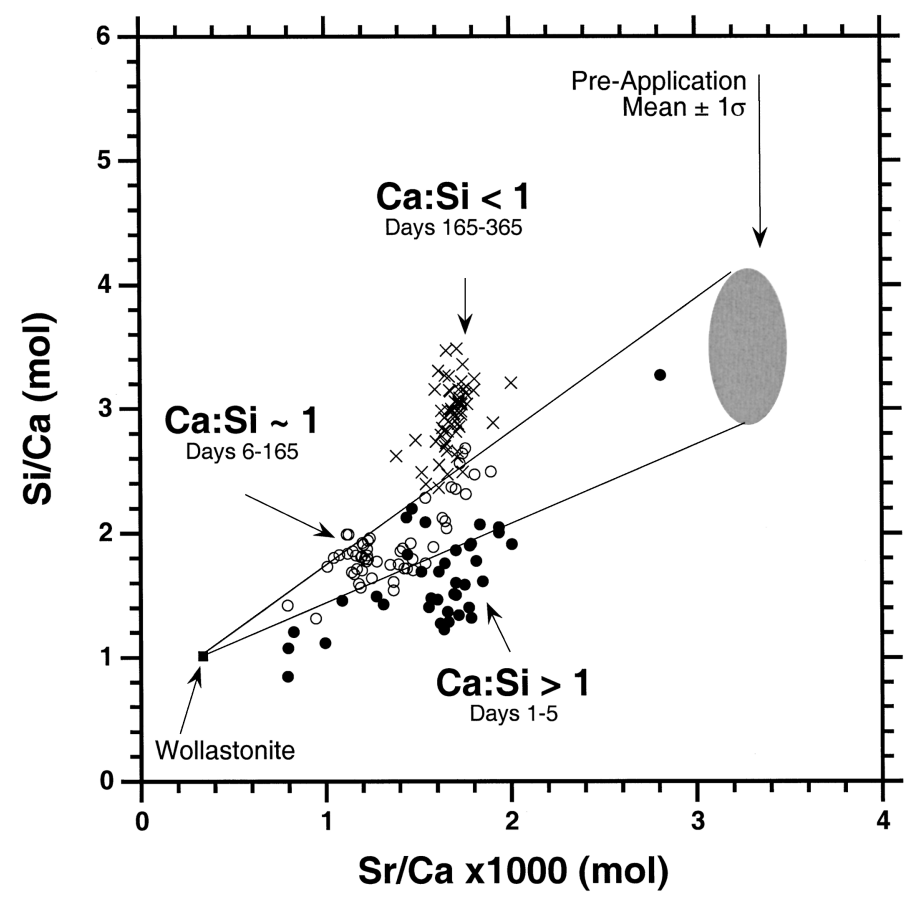

Figure 8. Plot of $\mathrm{Sr} / \mathrm{Ca}$ vs $\mathrm{Si} / \mathrm{Ca}$ for wollastonite and streamwater. Pre-application values and their $95 \%$ confidence interval are plotted on the right side of the graph. Tie lines connect the edges of the $95 \%$ confidence intervals with the wollastonite endmember. Data within this field are indistinguishable from 1:1 Ca:Si dissolution. Post application values are plotted in the middle of the graph. Initial values plot below the lower tie line indicating $\mathrm{Ca}>\mathrm{Si}$ release. Samples collected a few months after the application show 1:1 Ca:Si dissolution. Samples taken $>\sim 6$ months after the application show $\mathrm{Ca}<\mathrm{Si}$ release.

\section{Acknowledgements}

The authors would like to thank A. Klaue, S. Bailey, D. Buso, S. Palmer, J. Hogan, T.C.W. Ku and A. Jacobson for their contributions. The comments of two anonymous reviewers improved the manuscipt. Support for this study was provided by the National Science Foundation and the A. W. Mellon Foundation. The Hubbard Brook Experimental Forest is operated and maintained by the Northeastern Forest Experiment Station, U.S. Department of Agriculture, Newtown Square, Pennsylvania.

\section{References}

Bailey S.W., Hornbeck J.W., Driscoll C.T. and Gaudette H.E. 1996. Calcium inputs and transport in a base-poor forest ecosystem as interpreted by Sr isotopes. Water Resources Research 32: 707-719. Banfield J.F., Ferruzzi G.G., Casey W.H. and Westrich H.R. 1995. HRTEM study comparing naturally and experimentally weathered pyroxenoids. Geochimica et Cosmochimica Acta 59: 19-31. 
Berner R.A., Lasaga A.C. and Garrels R.M. 1983. The carbonate-silicate geochemical cycle and its effect on atmospheric carbon-dioxide over the past 100 million years. American Journal of Science 283: 641-683.

Blum A.E. and Stillings L.L. 1995. Feldspar dissolution kinetics. In: White A.F. and Brantley S.L. (eds), Chemical Weathering Rates of Silicate Minerals. Vol. 31. Mineralogical Society of America, Washington, DC, USA, pp. 291-346.

Blum J.D., Klaue A., Nezat C.A., Driscoll C.T., Johnson C.E., Siccama T.G. et al. 2002. Mycorrhizal weathering of apatite as an important Ca source in base-poor forest ecosystems. Nature 417: 729731.

Blum J.D., Taliaferro E.H., Weisse M.T. and Holmes R.T. 2000. Changes in $\mathrm{Sr} / \mathrm{Ca}, \mathrm{Ba} / \mathrm{Ca}$ and ${ }^{87} \mathrm{Sr} /{ }^{86} \mathrm{Sr}$ ratios between trophic levels in two forest ecosystems in the northeastern USA. Biogeochemistry 49: $87-101$.

Capo R.C., Stewart B.W. and Chadwick O.A. 1998. Strontium isotopes as tracers of ecosystem processes: theory and methods. Geoderma 82: 197-225.

Casey W.H., Banfield J.F., Westrich H.R. and McLaughlin L. 1993. What do dissolution experiments tell us about natural weathering. Chemical Geology 105: 1-15.

Chamberlin T. 1899. An attempt to frame a working hypothesis of the cause of glacial periods on an atmospheric basis. Journal of Geology 7: 545-584.

Cirmo C.P. and Driscoll C.T. 1996. The impacts of a watershed $\mathrm{CaCO}_{3}$ treatment on stream and wetland biogeochemistry in the Adirondack Mountains. Biogeochemistry 32: 265-297.

Drever J.I. and Zobrist J. 1992. Chemical-weathering of silicate rocks as a function of elevation in the southern Swiss Alps. Geochimica et Cosmochimica Acta 56: 3209-3216.

Driscoll C.T., Cirmo C.P., Fahey T.J., Blette V.L., Bukaveckas P.A., Burns D.A. et al. 1996. The experimental watershed liming study: Comparison of lake and watershed neutralization strategies. Biogeochemistry 32: 143-174.

Federer C.A., Flynn L.D., Martin C.W., Hornbeck J.W. and Pierce R.S. 1990. Thirty Years of Hydrometric Data at the Hubbard Brook Experimental Forest, New Hampshire. USDA General Technical Report NE-141..

Gerdes M. and Valley J. 1994. Fluid flow and mass-transport at the Valentine wollastonite deposit, Adirondack Mountains, New York State. Journal of Metamorphic Geology 12: 589-608.

Grove E.R., Beig M.S. and Luttge A. 2000. Wollastonite dissolution kinetics: temperature, pH dependence, and the formation of leached layers studied by VSI. In: Abstracts with Programs. Geological Society of America, Reno, NV, USA.

Hall R.O., Macneale K.H., Bernhardt E.S., Field M. and Likens G.E. 2001. Biogeochemical responses of two forest streams to a 2-month calcium addition. Freshwater Biology 46: 291-302.

Hogan J.D., Blum J.D. and Driscoll C.T. 2000. Concentration-discharge relationships during storm events at the Hubbard Brook Experimental Forest. In: EOS, Transactions, San Francisco, (p F465). American Geophysical Union.

Hyman M.E., Johnson C.E., Bailey S.W., April R.H. and Hornbeck J.J. 1998. Chemical weathering and cation loss in a base-poor watershed. Geological Society of America Bulletin 110: 85-95.

Johnson C.E., Driscoll C.T., Siccama T.G. and Likens G.E. 2000. Element fluxes and landscape position in a northern hardwood forest watershed ecosystem. Ecosystems 3: 159-184.

Johnson C.E., Johnson A.H., Huntington T.G. and Siccama T.G. 1991. Whole-tree clear-cutting effects on soil horizons and organic-matter pools. Soil Science Society of America Journal 55: 497-502.

Johnson N.M., Driscoll C.T., Eaton J.S., Likens G.E. and McDowell W.H. 1981. "Acid rain", dissolved aluminum and chemical weathering at the Hubbard Brook Experimental Forest, New Hampshire. Geochimica et Cosmochimica Acta 45: 1421-1437.

Johnson N.M., Likens G.E., Bormann F.H. and Pierce R.S. 1968. Rate of chemical weathering of silicate minerals in New Hampshire. Geochimica et Cosmochimica Acta 32: 531-545.

Kendall C. and MacDonnell J.J. 1998. Isotope Tracers in Catchment Hydrology. Elsevier.

Kump L.R., Brantley S.L. and Arthur M.A. 2000. Chemical, weathering, atmospheric $\mathrm{CO}_{2}$, and climate. Annual Review of Earth and Planetary Sciences 28: 611-667. 
Likens G.E. and Bormann F.H. 1995. Biogeochemistry of a Forested Ecosystem. Springer-Verlag, New York, NY, United States.

Likens G.E., Driscoll C.T. and Buso D.C. 1996. Long-term effects of acid rain: Response and recovery of a forest ecosystem. Science 272: 244-246.

Likens G.E., Driscoll C.T., Buso D.C., Siccama T.G., Johnson C.E., Lovett G.M. et al. 1998. The biogeochemistry of calcium at Hubbard Brook. Biogeochemistry (Dordrecht) 41: 89-173.

Mast M.A., Drever J.I. and Baron J. 1990. Chemical-weathering in the Loch Vale Watershed, RockyMountain- National-Park, Colorado. Water Resources Research 26: 2971-2978.

Paces T. 1983. Rate constants of dissolution derived from the measurements of mass balance in hydrological catchments. Geochimica et Cosmochimica Acta 47: 1855-1863.

Rimstidt J.D. and Dove P.M. 1986. Mineral solution reaction-rates in a mixed flow reactor - wollastonite hydrolysis. Geochimica et Cosmochimica Acta 50: 2509-2516.

Swoboda Colberg N.G. and Drever J.I. 1993. Mineral dissolution rates in plot-scale field and laboratory experiments. Chemical Geology 105: 51-69.

Velbel M.A. 1985. Geochemical mass balances and weathering rates in forested watersheds of the southern Blue Ridge. American Journal of Science 285: 904-930.

Velbel M.A. 1993. Constancy of silicate mineral weathering-rate ratios between natural and experimental weathering - Implications for hydrologic control of differences in absolute rates. Chemical Geology 105: 89-99.

Weissbart E.J. and Rimstidt J.D. 2000. Wollastonite: Incongruent dissolution and leached layer formation. Geochimica et Cosmochimica Acta 64: 4007-4016.

Xie Z.X. and Walther J.V. 1994. Dissolution stoichiometry and adsorption of alkali and alkaline-earth elements to the acid-reacted wollastonite surface at 25 degrees C. Geochimica et Cosmochimica Acta 58: 2587-2598. 